of Pompeii and Herculaneum, so the subject of antiquarian studies, and especially the rise of new comparative disciplines of intellectual inquiry, constitutes the basis of Alain Schnapp's essay. Modern archaeology and ethnology, Schnapp suggests, were the results of a transformation away from "curiosities" and represented a "fresh way of looking at antiquity" (157). This sparked a hunt for antiquities throughout the eastern Mediterranean. The final essay is Antonino De Francesco's provocatively-titled "How Not to Finish a Revolution", which examines the shortlived Jacobin Republic in 1799. He notes several interesting comparisons between the French and Neapolitan Revolutions, but the essay lacks a clear argument. The bicentennial of the Neapolitan Revolution several years ago sparked a wave of new books, in both Italian and English, which might prove a more useful guide to the events of that era.

\title{
Christopher CARLSMITH
}

University of Massachusetts Lowell

Niccolò Tommaseo e Firenze. Atti del convegno di studi, Firenze, 12-13 febbraio 1999, eds. Roberta Turchi, Alessandro Volpi. Firenze: Leo S. Olschki, 2000. Pp. xi, 384. ISBN 8-8222-4894-5.

Tommaseo's memories of his first weeks in Florence where, at the invitation of Giampietro Vieusseux, he had gone in 1827 from Milan were not happy ones. He wrote in his Memorie poetiche (1838) that "il primo soggiorno in una città, fra nuovi uomini e nuove cose, fu sempre tristo a me, quel di Firenze tristissimo". But seven years later, from his self imposed exile in France that had come about when Vieusseux's Antologia was suppressed for political reasons, his attitude was quite different. In a poignant letter to one of his closest friends, Gino Capponi, Tommaseo expresses his longing for the city: "oh, dov'è la mia Firenze, e i miei giorni fitti nel pensiero, e il mio pensiero italiano tutto?" (Tommaseo e Capponi, Carteggio inedito, 29 May 1834).

The events of Tommaseo's life and career that led to his nostalgic embrace of Florence and eventually, after all the tumultuous undertakings of a career as author, poet, pedagogue, linguist, philosopher, apologist for Christianity, to permanent residence in Florence is the focus of this recent collection of essays.

The 19 studies, divided into three sections entitled respectively "Il pensiero politico e religioso", 'L'Opera letteraria e linguistica" and "La vicenda biografica", offer us an Italian and also, on a larger scale, a European overview, of Tommaseo's accomplishments and attitudes in the city he loved above all others. In Florence were his best friends, his most notable literary achievements and much much later, his beloved family. However, as the preface justly indicates, Tommaseo's contact with Florence expanded far beyond the city and had a seminal effect on the definition of an Italian "national" language, a concept towards which the Dalmatian author worked assiduously, in blindness, in poverty, in old age, until his death in 1874.

The opening essay by Franco della Peruta, "Nazionalità e Risorgimento fino alla rivoluzione del '48," sets the historical ambience in which Tommaseo operat- 
ed in the years between his sojourns in Florence. These were years in which, as the following piece, "Vita civile e storia nazionale. Tommaseo e i moderati toscani," by Luigi Mascilli Migliorini, Tommaseo's concept of Italianness is formed, as together with his contemporaries Manzoni and Sismondi he reaches back into the Middle Ages to find the origins of an Italian identity. These are the years of his study of Dante, and of his historical novellas. These are also the years of his intensive reflection on the role of the Church and of the Catholic religion on the political environment in Italy, as Guido Verucci points out in the essay following. Verucci shows how the works of Tommaseo at this time reflect the influence of his friendship with Antonio Rosmini. Politics and faith are concepts that frame Tommaseo's reflections on the Slavic peoples as well; ever mindful of his deep respect for his roots, and especially for his mother, Tommaseo never forgot that he came from the Dalmatian coast. The anthology contains several other essays that deal with Tommaseo and his relationship with his Dalmatian roots, including "Il destino dei popoli slavi nella prospettiva europea di Niccolò Tommaseo" by Arduino Agnelli, "La scoperta della poesia popolare" by Giovanni Battista Bronzini and "Tommaseo e la Serbia" by Nikša Stipčević. The sociopolitical observations of the first essay regarding the Slavic peoples complement the more literary assertions and comments of the latter two, and certainly all three pieces elucidate Tommaseo's belief that " $[\mathrm{p}]$ roprio $\mathrm{i}$ popoli, che più hanno sofferto e più a lungo sono stati privati della libertà, possono...mantenere una purezza di spirito, che gli altri hanno perduto" (105). Clearly, as Raffaele Ciampini had already ably demonstrated in his Vita di Niccolò Tommaseo (Firenze, 1945), Tommaseo included himself among this group, both in his acquired Italianness and in his Slavic roots. One curiosity among these three essays is the omission of the work done on Tommaseo, as regards his enquiries and interest into matters Slavic, by the Rivista dalmatica which has always promoted him as being of Dalmation origin.

Tommaseo as author is the focus of the third section of this collection. He is represented in two ways: as narrator and poet, and also as journalist (for lack of a better term). Tommaseo had no family fortune to support his writing endeavours, as had many of his contemporaries and friends. In fact, he remained, until death, a man of limited means, among whose letters we find reference, near the end of his life, to a cravat that he was still wearing at that time, although he had acquired it, and already second-hand at that, in 1838 . When we realize how much Tommaseo depended on writing for his livelihood, Roberta Turchi's opening in her essay on the author's contributions to Vieusseux's Antologia becomes all the more meaningful, although the essay takes an academic and critical approach. Turchi quotes a letter of September 1823 in which Vieusseux writes to Giacomo Leopardi that Tommaseo "lavora sempre molto; ed anche troppo, e soprattutto troppo presto." The alacrity of his production may have slowed down in later years, but his prolific output certainly did not. It was, in fact, by dint of unrelenting and hard work that Tommaseo earned his place in the world of Italian letters as the essays of Donatella Martinelli ("Il Nuovo dizionario de' sinonimi della lingua italiana, da Milano a Firenze"), Massimo Fanfani ("Niccolò Tommaseo e 
l'Accademia della Crusca") and Giorgio Bàrberi Squarotti ("Il Vocabolario del Tommaseo") confirm.

The closing essays of the book expand and comment on the biographical information we have of Tommaseo. Aglaia Paoletti Langé addresses Tommaseo's earliest years in Florence, Marco Cini his exile, Veronica Gabbrielli the last years of his life, from 1859-1874. This was the period when he took up permanent residence in the city. Marco Cignotti studies Tommaseo's relationship with various Florentine publishers, including Vieusseux, Le Monnier and Barbèra. Virgilio Missori's essay stands out for its presentation and analysis of Tommaseo's copious correspondences while Arnaldo Colasanti focuses on the problematic Diario intimo, which he concludes, is an inspired book (362). Here Tommaseo, with great agility, manipulates truthsand desires, but leaves us, nonetheless, with what Colasanti calls 'the gift of familiarity' (363).

Obvious in these last few essays, more than in the others, is the sense that Tommaseo remains a beloved, respected figure, despite his difficult nature. Colassanti writes that "[1] a parola in Tommaseo è esorbitante, è un dominio. Ma le parole, per noi uomini, sono anche l'unica cosa che abbiamo: occorre amarle, cercarle, rispettarle" (371). In these words is the spirit of Tommaseo's life work, a spirit that remains long after his death, and that the authors of the essays in this fine volume have captured and respected.

\section{ANNE URBANCIC \\ University of Toronto}

\section{Doumanis, Nicholas. Italy. Inventing the Nation Series. NY: Oxford University Press/ London: Arnold, 2001. Pp. x, 190. ISBN 0-3406-9161-1. US. \$39.95.}

The Inventing the Nation Series seeks to show how various geographic communities have forged themselves into nations, bringing various peoples into the fold of a similar set of identities, a shared past, and a sense of a common future. As the series editor, Keith Robbins, as well as the author point out, Italy is one of the best European examples of such a conscious effort in creating a nation. Despite current abhorrence for 'nationalism' - a term hallmarked by xenophobia and intolerance during the late nineteenth and twentieth centuries-this sentiment was effectively employed by many countries in the modern era to unite diverse peoples. While this process was often deliberate, it had to appear natural; according to Doumanis, 'for an invented nation to be seen as legitimate, the very fact that it was constructed had to be concealed.'

Aware of the dangers inherent in attempting to explain something as intangible as 'identity', Doumanis explores the material evidence for the building of italianità. Working chronologically, he discusses the various factors, such as inter-state politics and capitalism, that led to the beginning of the revolts in the nineteenth century. In the first chapter, he briefly describes what he terms as the nation's prehistory, c. 1000-1796. Although history would be one of the two major backbones 